\title{
高速ロボットハンドシステムの人間機械協調動作への応用
}

\author{
山川 雄司 ${ }^{* 1}$, 久野 和生 ${ }^{* 2}$, 石川 正俊*3
}

\section{Application of high-speed robot hand system to human-robot cooperative motion task}

\author{
Yuji YAMAKAWA ${ }^{* 1}$, Kazuki KUNO ${ }^{* 2}$ and Masatoshi ISHIKAWA ${ }^{* 3}$ \\ ${ }^{* 1,{ }^{*} 3}$ Graduate School of Information Science and Techonology, The University of Tokyo \\ 7-3-1 Hongo, Bunkyo-ku, Tokyo 113-8656, Japan \\ ${ }^{* 2}$ Graduate School of Interdisciplinary Information Studies, The University of Tokyo \\ 4-6-1 Komaba, Meguro-ku, Tokyo 153-8505, Japan
}

Received 4 August 2016

\begin{abstract}
We demonstrated a high-speed human-robot cooperation task using a high-speed robot hand system consisting of a highspeed vision system, an image processing PC, a high-speed robot hand, a high-speed tactile sensor (only for measurement) and a real-time controller. In particular, our goal was to achieve a concrete task in which a board grasped by both a human subject and a robot hand is always kept horizontal by controlling the robot hand based on high-speed visual feedback using the vision system. We propose a basic strategy for appropriately achieving the task and discuss an image processing procedure for detecting the state of the board (position and angle). Also, we describe the inverse kinematics of the robot hand so as to keep the board horizontal, and we set limitations for the robot hand joint angles for avoiding an error action due to human error. Finally, we show experimental results for the human-robot cooperation task achieved using the highspeed robot system and our proposed method, and we compare the experimental results between low frame rate and high frame rate in terms of response time and reaction force detected by a high-speed tactile sensor.
\end{abstract}

Key words : Human-robot cooperation, High-speed robot hand, High-speed vision

\section{1. 緒言}

近年，様々なロボット開発が行われ，人間社会にロボットが参入してきている. 特に，人間とロボットが直接的 に関わり合うような場面では，人間とロボットが相互に作用しあうために，人間とロボットが協調するシステム が必要であり, 今後重要なロボット技術となる.

その一方で, 工場や FA (Factory Automation) 等の様々な場面においても, 多種多様なロボットが導入されてい る.これらのロボットは, いかに正確に, かつ効率良く作業を行うか等が重要視され, 高速に動作するロボット 等も開発されている.

本研究では, これらの背景の下に, 主に高速ビジョンと高速ロボットハンドから構成される高速ロボットハン ドシステムを用いて, 人間と高速ロボットによる人間ロボット協調システムを構築する. これにより, 協調動作を 実現するだけでなく，人間の高速な動作やランダムな動作にも瞬時に対応できると考えられる.

\footnotetext{
No.16-00352 [DOI: 10.1299/transjsme.16-00352], J-STAGE Advance Publication date : 2 December, 2016

*1 正員, 東京大学大学院情報理工学系研究科( ⿳113-8656 東京都文京区本郷 7-3-1)

*2 東京大学大学院学際情報学府(T153-8505 東京都目黒区駒場 4-6-1)

*3 正員, フェロー, 東京大学大学院情報理工学系研究科

E-mail of corresponding author: Yuji Yamakawa@ipc.i.u-tokyo.ac.jp
} 
High-speed Human Robot Cooperative System

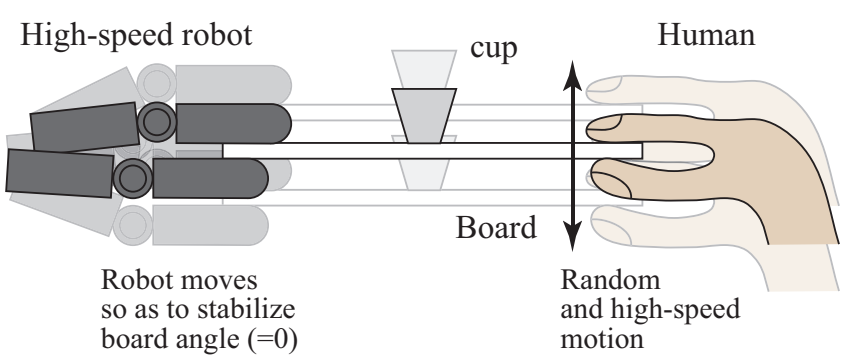

Fig. 1 Concept of this reseach (cooperative task between human and high-speed robot)

\section{$1 \cdot 1$ 関連研究}

これまでにも，人間とロボットの協調作業に関する様々な研究が行われてきた。例えば，人間とロボットの協 調形態を分類する研究 (中内, 安西, 1992), (Kazerooni, 1993), (Kazerooni, 1995) や，協調システムのモデリングに関 する研究 (池浦, 2000a), (池浦, 2000b) 等が行われてきた。人間と協調するロボットの持つべき機能やその用途につ いても考察されている (佐藤, 1996), (佐藤, 森, 1999). また, 人間と協調して特定の動作を行うロボットの研究と して，物体を持ち上げる協調ロボットに関する研究 (小菅他, 1999), (Al-jarrah and Zheng, 1997), 物体を運搬する協 調ロボットに関する研究 (Hayashibara et al., 1999), (Yokoyama et al., 2003)や，特異姿勢における人間との協調に関 する研究 (Nakai et al., 2002) 等が行われている.

一方，高速ビジョンを用いてロボットの高速性を活かした研究として，人間が投げたボールをトラッキングし， バッティングするロボットアームの研究 (妹尾他, 2006), 把握動作を行う高速センサフィードバックの研究 (並木 他, 2002) やZMP 規範の制御から脱却した高速二足走行ロボットの研究 (玉田他, 2015) 等が挙げられる. しかし, これらはロボット単体での動作生成や運動制御に関する研究であり，人間と協調するものではない.

本研究では，人間機械協調系へ高速ビジョンと高速ロボットハンドを組み合わせたシステムを適用し，運動系 において人間と高速に協調する動作の実現を目指す．高速なロボットシステムを用いることにより，人間の動作 や物体の運動を瞬時に計測し，反応することができるため，低遅延での人間との協調動作を可能にし，人間が口 ボットの運動に気を遣うことなく，タスクが実現されると期待できる．将来的には，人間の動作に対し先回りし て，動作・支援することも可能になると考えられ，人間機械協調の新しい機能を生み出すものと考えられる.

\section{2 目的}

本研究では，人間とロボットによる協調作業の中でも，図 1 に示す人間とロボットが一つの物体を協調して支 え，常に物体を水平状態に保持するという人間機械協調動作において基本的なタスクケースについて考える. 物体 は板状のものとし，一端を人間が支え，他端をロボットハンドが支えるとする．以降，操作対象である板を「物 体」と呼ぶことにする．また，本論文では，物体の上下運動のみを考慮する.

例えば，お盆に水の入ったコップが乗っているような状況を想定すると，コップの水がこぼれないように，常に お盆を水平状態に保たせる必要がある，そのため，人間とロボットが協調して支える場合には，人間の支える端 が上下に移動した際に，それに応じてロボットハンドの支える端も同じだけ上下に移動させ，水平を保つように しなければならない。このように，人間の手の動きに合わせてロボットハンドを制御し，常に物体が水平状態を 保つシステムを開発することが本研究の目的である．本目的を達成するためには，計測（センシング）と運動制 御（アクチュエーション）の両方の高速性が求められ，著者らが進めている高速ロボットシステムを応用するこ とを考える。

本タスクはロボットハンドと人間の手の協調作業の基本的な動作と考えられ，高速ロボットハンドシステムを 人間機械協調系へ適用した研究例として妥当と考えられる. 先行研究 (小菅他, 1999), (Al-jarrah and Zheng, 1997), (Hayashibara et al., 1999), (Yokoyama et al., 2003) が類似のタスクを実現していることからも，本タスクは人間機械 協調系の検証実験として有意義であると考えられる．また，提案システムを拡張することにより，様々な人間機械 協調系への応用展開が可能になる．例えば，人間と一緒に大きな物体を搬送し作業するタスクや，人間がラフに 動作しても最終的にロボットが微調整（例：位置合わせ）するタスク等が考えられる. 


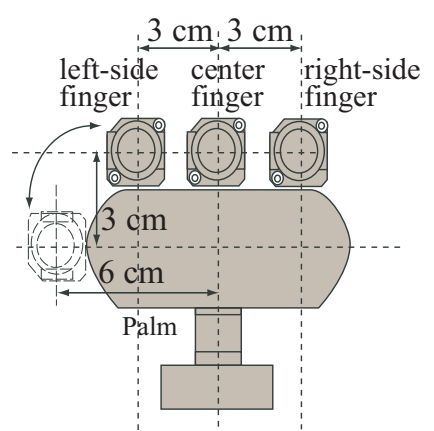

(a) Front view

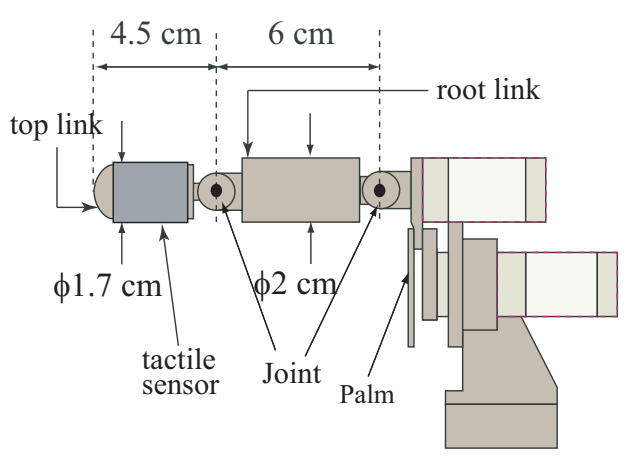

(b) Side view

Fig. 2 High-speed robot hand

本論文では, 構築した高速な人間機械協調システムの詳細を述べ, タスク実現の戦略とともに成功例を示し (Yamakawa et al., 2015), (石川渡辺研究室, 2015), 高速ロボットシステムの人間機械協調への適用可能性を示す.

構築した高速な人間機械協調システムの特徵は,

1. 高速ビジョンを用いて物体の状態を高速かつ正確に把握することで, 人間の運動を計測することなくタスク を遂行できる

2. インピーダンス制御や力制御のような人間のモデルを必要とせず，ロボットシステムの高速性により幾何学 的な計算のみで人間機械協調を実現できる

といった，比較的簡易な方法で人間機械協調に関するタスクが実現出来る点である．しかしながら, 幾何学的な 計算のみの提案手法は高速性から実現されうる方法であるため，高速ビジョンのフレームレートを低下させた場 合のシステムの応答性について考察し, 提案手法の適用可能なフレームレートについて明らかにする.

上述特徵に加えて, 人間の複雑な運動を計測することなく, 物体の状態を計測するだけで実現できる点は, 画像 処理認識やロボット制御の簡易化につながると考えられる。さらに，インピーダンス制御や力制御では物体の位 置・姿勢に合わせたロボットの制御が困難であるが，提案手法では画像により物体の位置・姿勢状態が計測でき るため, 適切なロボット制御も可能になると考えられる.

\section{2. 高速ロボットハンドシステム}

本システムは高速ビジョン, 画像処理 PC, 高速ロボットハンド, 高速触覚センサ, 制御システムから構成され ている，以下に各要素の詳細を述べる.

\section{$2 \cdot 1$ 高速ビジョン}

ロボットハンドと人間の手で支える物体の状態を計測する検出部として高速ビジョンを用いた。本実験で使用 した高速ビジョン（EoSens）の最大解像度は $1280 \times 1024$ pixel であり，フルフレームでの最大フレームレートは $500 \mathrm{fps}$ である. 高速ビジョンではフレームレートの高速性ゆえに露光時間が短く, 得られる画像は暗くなり, 物 体を認識しにくいために赤外 LED 照明を用いた。高速ビジョンは画像転送インタフェース CameraLink Full によ り画像処理 PC に接続されており，その PC 内で画像処理（詳細は 3.1 節）が行われ，その処理結果はイーサネッ トにより，リアルタイムで制御システムに送信される.

\section{$2 \cdot 2$ 高速ロボットハンド}

物体を支え, 物体を水平状態に保つ操作を行う操作部として高速ロボットハンド (Namiki et al., 2003) を用いた. ロボットハンドの機構を図 2 に示す. 指の本数は 3 本であり, 左右の指には二つの関節に加え, 掌の面内で旋回 が可能であり，それぞれ 3 自由度を持つ。なお，本研究において旋回動作は使用していない. 中指は二つの関節 を持ち，2 自由度である．それぞれの関節の可動域を表 1 に示す．また，手首は屈曲・旋回の 2 自由度の動作が可 能であるが，本タスクにおいて手首の運動は使用していない. 
Table 1 Movable range of each joint of robot hand

\begin{tabular}{|c||c|}
\hline Joint & Movable range \\
\hline \hline Top and root links & $-\frac{\pi}{2} \sim \frac{\pi}{2}$ \\
\hline Rotation of left and right fingers & $0 \sim \pi$ \\
\hline Bending of wrist & $-\frac{\pi}{2} \sim \frac{\pi}{2}$ \\
\hline Rotation of wrist & $-\frac{\pi}{2} \sim \frac{\pi}{2}$ \\
\hline
\end{tabular}

このロボットハンドは高速な動作が可能であり，各関節を $0.1 \mathrm{~s}$ で 180 度回転させることが可能である. したがっ て, 本ロボットハンドの性能であれば，本研究で実現するタスクに対して，人間が高速かつランダムに物体を動 かしても，物体を水平状態に保持することが十分に可能であると考えられる.

\section{$2 \cdot 3$ 高速触覚センサ}

高速ロボットハンドへの反力を計測し，実駼結果を評価するために，ロボットハンドの指先リンクに高速触覚 センサ (石川, 下条，1982) を取り付けた。高速触覚センサは 1 ミリ秒以内の応答性を有し, 負荷の值と二次元負 荷の重心位置を計測することができる．なお，得られたデータは評価のみに使用し，高速ロボットハンドの制御 には用いていない.

\section{$2 \cdot 4$ 制御システム}

画像処理 PC を含むビジョンシステム，ロボットハンド，触覚センサのデータは制御システム（dSPACE）に送 信され，これらのデータを用いて制御システム内でロボットハンドの制御指令を計算し，出力している. 制御シ ステムは $1 \mathrm{kHz}$ のサンプリングレートで実行している.

\section{5 システムセットアップ}

実験システムの全体像を図 3 に示す．高速ビジョンは水平器を用いて地面に対して水平に，かつビジョンの光 軸の高さがロボットハンドと同じ高さとなるようにし，物体全体のみが映るように設置した。

\section{3. 人間機械協調戦略}

本章では，実際にタスクを実現するための基本戦略およびその戦略に基づく具体的な手法について述べる， ロボットシステムが物体を支え，人間が物体を上下運動させても物体が水平を保持するようにするための必要 な処理は，大きく以下の 3 つのステップに分けられる.

1. 人間の手とロボットハンドによって支えられている物体の傾きと重心位置を，高速ビジョンを用いて 画像処理により計算する. (3.1 節)

2. 1. で算出した傾きと重心位置を元に，物体の傾きを 0 にするためにロボットハンドのとるべき姿勢，す なわち各関節がとるべき角度を計算する. ( $3 \cdot 2$ 節， $3 \cdot 3$ 節)

3. 2. で算出した各関節のとるべき角度になるよう，ロボットハンドを制御する. (3.4 節)

図 4 に基本戦略の概要を示す．上記 3 つのステップを高速なサンプリングレートで繰り返すことにより，人間 とロボットハンドによって支えられた物体を常にほぼ水平状態に保つことが可能になる．本提案手法はロボット システムの高速性により実現可能な方法であるため，本手法が適用可能な範囲をフレームレートの観点から明ら かにする.

ロボットハンドによる物体の把持は，左右の指で物体を下から，中指で物体を上から支えることで，物体を挟 み込む形にすることにより，安定した把持を可能にした。 


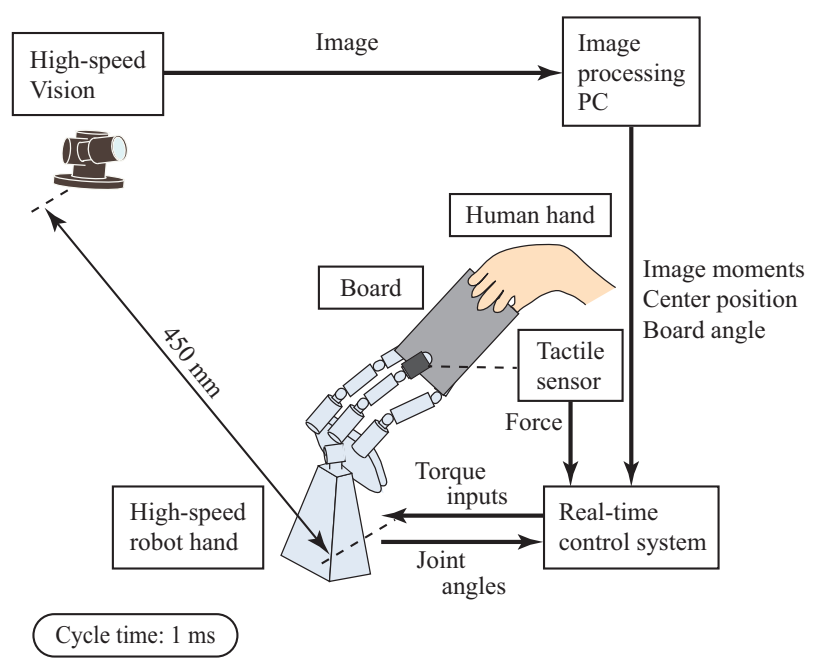

Fig. 3 System overview

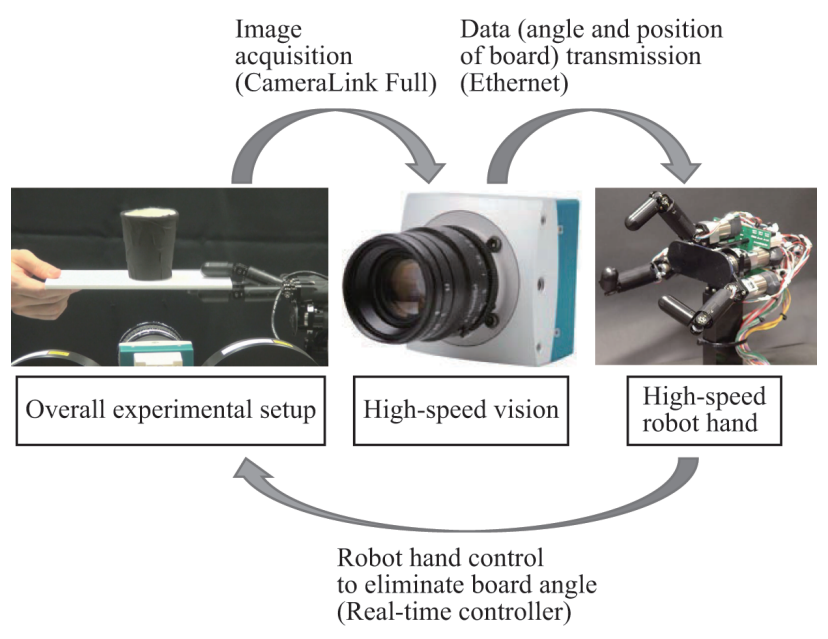

Fig. 4 Overall of motion strategy

\section{$3 \cdot 1$ 物体の状態計測}

物体の状態計測として，高速ビジョンを用いた物体の傾き $\left(\theta_{m}\right)$ と重心位置 $\left(g_{x}, g_{y}\right)$ (=画像内での物体中心 位置）の計測方法について説明する（図 5)．なお，物体は上下運動のみに限定するため，紙面に対する奥行き方 向は考慮していない。

物体を真横から観測することとし，かつ物体全体が映るように高速ビジョンを設置し，物体全体が映っている 画像を取得する。適切な閾值を設定し，得られた画像を二值化することで物体だけを捉えた画像が得られ，その 画像に対して物体の傾きおよび重心位置を計測する，ただし，この時得られる傾きは高速ビジョンに対する傾き のため，高速ビジョンをあらかじめ水平になるよう設置している.

二值化した画像から傾きおよび重心位置を求めるために画像モーメントを用いた. $(i+j)$ 次の画像モーメント $m_{i, j}$ は

$$
m_{i, j}=\sum_{x} \sum_{y} x^{i} y^{j} f(x, y)
$$

と定義される．ここで， $(x, y)$ は画像内の座標（ピクセル值）であり， $f(x, y)$ は画像内の各ピクセルにおける二值 である（物体がある場所では 1 ，それ以外の場所では 0$)$.

このとき, $m_{0,0}$ は物体の面積, $m_{1,0}$ は $x$ 座標の和, $m_{0,1}$ は $y$ 座標の和を表し, 物体の重心座標 $\left(g_{x}, g_{y}\right)$ は

$$
\left(g_{x}, g_{y}\right)=\left(\frac{m_{1,0}}{m_{0,0}}, \frac{m_{0,1}}{m_{0,0}}\right)
$$

となる.ここで, $M_{i, j}$ を

$$
M_{i, j}=\sum_{x} \sum_{y}\left(x-g_{x}\right)^{i}\left(y-g_{y}\right)^{j} f(x, y)
$$

と定義すると, 物体の傾き $\theta_{m}$ は

$$
\theta_{m}=\frac{1}{2} \tan ^{-1}\left(\frac{2 M_{1,1}}{M_{2,0}-M_{0,2}}\right)
$$

から求められる．ただし，人間の手で支える端がロボットで支える端より低い場合の傾きを正方向とする.

\section{$3 \cdot 2$ ロボットハンドの逆運動学}

前節の方法を用いて高速ビジョンから計測された物体の傾き $\theta_{m}$ と重心位置 $\left(g_{x}, g_{y}\right)$ を元に, 物体を水平に保 つためのロボットハンドの各関節の適切な角度を計算する方法を説明する.

物体の傾きと重心位置を計測できれば，人間が支える物体の端に比ベ，ロボットハンドの支える端がどれだけ 高いか，もしくは低いかを計算することができる．物体を水平にするにはこの差を埋めるようにロボットハンド 


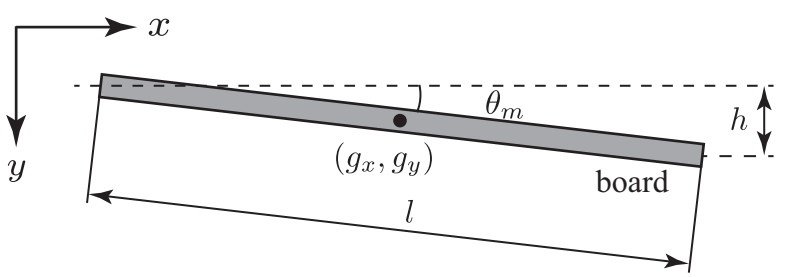

Fig. 5 Board state

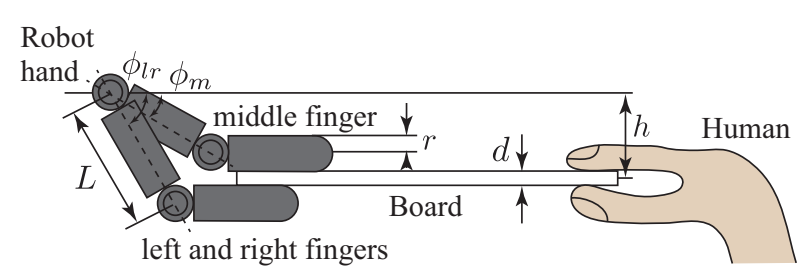

Fig. 6 Inverse kinematics of robot hand

の各指の高さを調整すればよい。このとき，ロボットハンドは図 6 に示す指配置で物体を支えるため，左右の指 はその上面が物体の下面に一致する位置に，中指はその下面が左右の指の上面より物体の厚さ分だけ高くなる位 置に制御する．ロボットハンドにより物体を上方向に移動させるとき，左右の指は板を持ち上げ，中指は板が指か ら離れないように抑える，一方，物体を下方向に移動させるときは，逆の動作となる.

初期状態において，物体は水平である $\left(\theta_{m}=0\right)$ とし，そのときの物体の重心の座標を $\left(g_{x}, g_{y}\right)=(0,0)$ とする. 人間が物体を操作し, 物体に運動が生じた際 $\left(\theta_{m}, g_{x}, g_{y}\right.$ が変化), 人間の手で支えている側の物体の端の高さ を $h$ とし，物体の長さを $l$ とすると

$$
h=g_{y}+\frac{l}{2} \sin e=g_{y}+\frac{l}{2} \sin \left(\theta_{m}-\theta_{d}\right)=g_{y}+\frac{l}{2} \sin \theta_{m}
$$

となる．ただし，傾きと同様，人間の手が支える端が基準として定めた初期位置より下がった場合を正とする．ま た，ロボットハンドの指の先端関節より先の部分を水平にするためには，根元の関節と先端の関節の角度が互い に絶対值が等しく, 符号が逆となればよいので, 根元の関節角度を計算すれば十分である. ここで, $e\left(=\theta_{m}-\theta_{d}\right)$ は実際の物体の傾きと目標とする物体の傾きとの誤差を示しており, 本研究では, 物体の傾きを水平 $\left(\theta_{d}=0\right) に$ するため, 誤差は $e=\theta_{m}$ となる.

物体の厚さを $d$, ロボットハンドの指の根元関節から先端関節までの距離を $L$, 指の半径を $r$, 左右の指の根元 の関節角を $\phi_{l r}$, 中指の根元の関節角を $\phi_{m}$ とすると, 図 6 より

$$
\begin{aligned}
& L \sin \phi_{l r}=h+r+d / 2 \\
& L \sin \phi_{m}=h-r-d / 2
\end{aligned}
$$

となり,

$$
\begin{aligned}
\phi_{l r} & =\sin ^{-1}\left(\frac{h+r+d / 2}{L}\right) \\
\phi_{m} & =\sin ^{-1}\left(\frac{h-r-d / 2}{L}\right)
\end{aligned}
$$

と求められる．ただし，根元の関節が下側に回転した時を正としている．また，左右の指と中指の先端の関節の 角度はそれぞれ $-\phi_{l r},-\phi_{m}$ となる。

\section{$3 \cdot 3$ 関節角度の制限}

ロボットハンドの各関節の可動域は表 1 の通りであり，指の動きに制限を加えず，物体を自由に動かしてしまう と関節角の可動域を超え, 誤動作を起こす可能性がある. そのため, 本研究では安全上の観点から, 各指の関節 角を図 7 のように -60 度〜 60 度の範囲に制限した。

このとき, 中指の根元の関節角度がとりうる最大值を $\phi_{\text {mmax }}$, 最小值を $\phi_{m m i n}$, 左右の指の根元の関節角度の最 大值を $\phi_{\text {lrmax }}$, 最小值を $\phi_{\text {lrmin }}$ とおくと, 図 7(a) の場合,

$$
\begin{aligned}
& \phi_{\text {lrmax }}=\frac{\pi}{3}[\mathrm{rad}](=60[\mathrm{deg}]) \\
& L \sin \phi_{\text {mmax }}=L \sin \phi_{\text {lrmax }}-2 r-d
\end{aligned}
$$




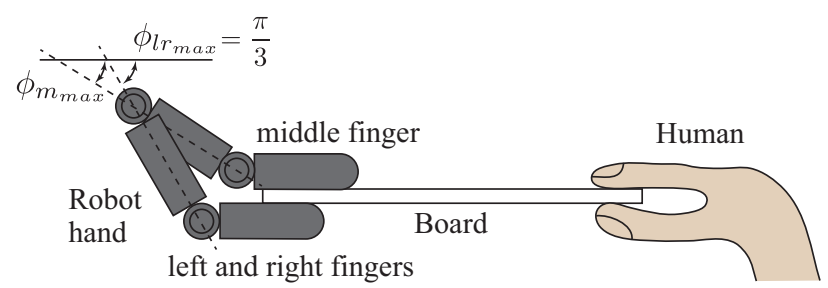

(a) Lower limit

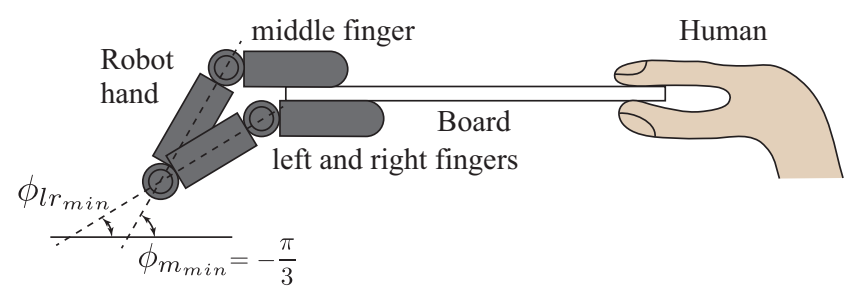

(b) Upper limit

Fig. 7 Limitation of joint angles

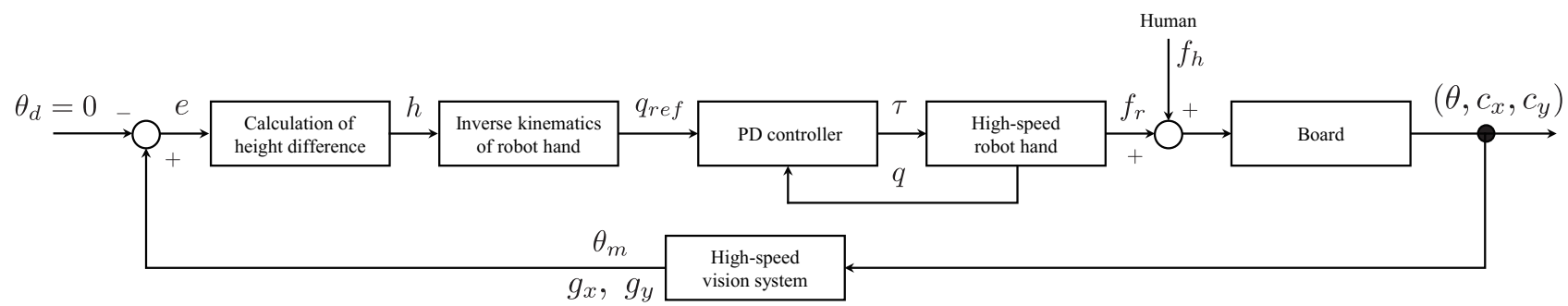

Fig. 8 Block diagram of overall control system

より

$$
\phi_{\text {mmax }}=\sin ^{-1}\left(\frac{L \sin \phi_{\text {lrmax }}-2 r-d}{L}\right)
$$

となる。一方，図 7(b) の場合，

$$
\begin{aligned}
& \phi_{\text {mmin }}=-\frac{\pi}{3}[\mathrm{rad}](=-60[\mathrm{deg}]) \\
& L \sin \phi_{\text {lrmin }}=L \sin \phi_{\text {mmin }}+2 r+d
\end{aligned}
$$

より

$$
\phi_{\text {lrmin }}=\sin ^{-1}\left(\frac{L \sin \phi_{\text {mmin }}+2 r+d}{L}\right)
$$

となるように制限すればよい。

以上から求められた各関節角度 $\left(\phi_{m}, \phi_{l r}\right)$ をロボットハンドの目標関節角度 $q_{r e f}$ とし，以下に述べる関節角度に 対するPD 制御が行われる.

\section{4 ロボットハンドの関節角度制御}

ロボットハンドの関節角度は目標関節角度に対する PD 制御により制御される。ロボットハンドの実際の各関節 角度を $q$, 目標関節角度を $q_{r e f}$ とし, 駆動トルク $\tau$ を次のように与える.

$$
\tau=k_{p}\left(q_{r e f}-q\right)+k_{d}\left(\dot{q}_{r e f}-\dot{q}\right)
$$

ここで， $k_{p}$ は比例ゲイン， $k_{d}$ は微分ゲインである. ロボットハンドの制御周期は $1 \mathrm{~ms}$ である.

関節角度制御が PD 制御のため，定常的には目標関節角度と実際の関節角度にオフセットが生じてしまうが，そ のオフセットは十分に小さいことを確認しており，タスク実現に影響しない。また，画像情報のノイズの影響も受 けないことを確認している。

本タスクに対するロボットシステムの制御系を図 8 に示す。 $\theta$ は実際の物体の傾き， $c_{x}, c_{y}$ は実際の物体の重心 位置， $f_{h}, f_{r}$ はそれぞれ人間とロボットハンドが物体に加える力， $\theta_{m}, g_{x}, g_{y}$ は高速ビジョンによって測定した 物体の傾きと画像上での重心座標， $\theta_{d}$ は物体の目標の角度であり，本研究では常に0である $\left(\theta_{d}=0\right)$.

今回構築したシステムにおいて,$x$ 方向の運動機構の自由度を有していないため, $g_{x}$ に関する補償は行わず， $\theta_{m}$ ， $g_{y}$ に対してのみ補償制御を行っているが， $x$ 方向に対しても自由度を追加すれば同様の方法で補償できると考えら れる，その場合，人間とロボットとの協調動作による物体運搬が実現されることになる. 
Table 2 Experimental conditions

\begin{tabular}{|c||c|}
\hline Thickness of object & $6 \mathrm{~mm}$ \\
\hline Length of object & $220 \mathrm{~mm}$ \\
\hline Resolution of image & $720 \times 512$ pixel \\
\hline Motion time & $10 \mathrm{~s}$ \\
\hline Maximum joint angle & $60 \mathrm{deg}$ \\
\hline Length from center of index finger to camera lens & $450 \mathrm{~mm}$ \\
\hline
\end{tabular}

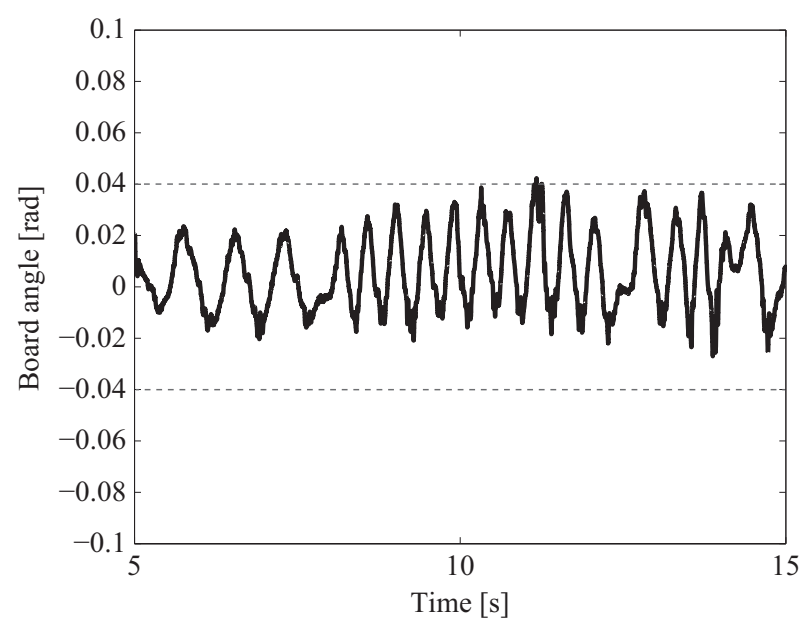

(a) Angle of object $\left(\theta_{m}\right)$

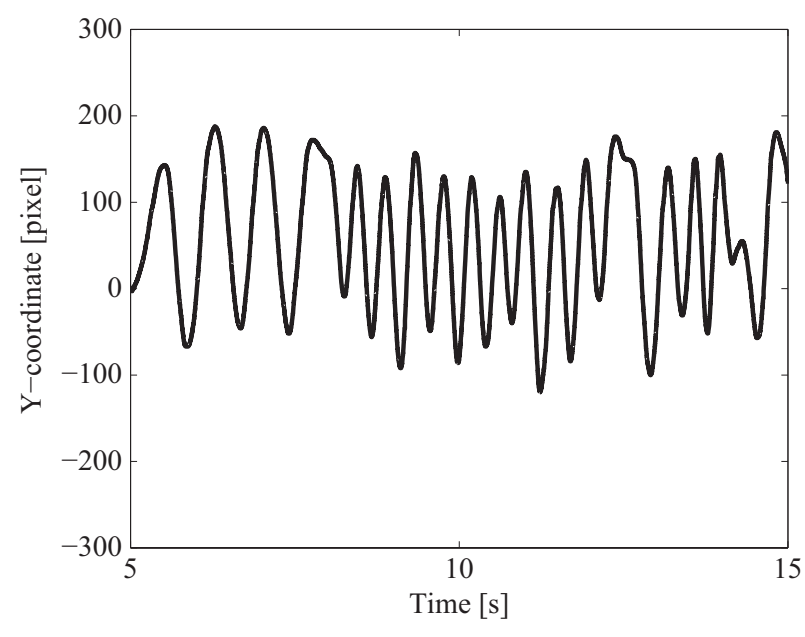

(b) $y$-coodinate of object $\left(g_{y}\right)$

Fig. 9 Experimental result (frame rate: $640 \mathrm{fps}$ )

\section{4. 実験}

2 章の構築システムに対して 3 章の提案手法を実装し, 実際に物体を水平に支える実験を表 2 に示す条件の下で 行った. フレームレートは可能な限り高くなるよう， $640 \mathrm{fps}$ に設定した.すなわち，ロボットハンドの目標関節 角度の更新レートは 1 ～2ミリ秒である. また，人間は物体を高速かつランダムに上下運動させた.

板にはコップを置き，人間が視覚的にタスク実現の様子を分かるようにした。なお，物体の把持力制御は実装 しておらず，逆運動学から得られた目標関節角度に対する関節角制御のみで物体を把持している.このとき，物 体は人間により上下運動可能であり, 把持力制御をしていないことによる本タスクへの影響はなかったことを実 験的に確認している.

\section{$4 \cdot 1$ 実験結果}

本実験において，物体を動かした被験者は 20 代男性 1 名と 30 代男性 1 名の計 2 名で，各 2 回実験を行った。ま た，被験者はシステムの動作を理解した上で，物体をランダムに上下運動させた.

本実験における実際の物体の傾き $\left(\theta_{m}\right)$ と重心の $y$ 座標 $\left(g_{y}\right)$ の変動を図 9 に示す. 図 9(a) は物体の傾き（ $\left.\theta_{m}\right)$ を, 図 9(b) は重心の $y$ 座標 $\left(g_{y}\right)$ を示している.ただし, 実験でデータを記録している 20 秒のうち, 初めの 5 秒 はロボットハンドが初期姿勢に移るための準備時間であり，この期間で人間とロボットが板を把持する．終わりの 5 秒は元の姿勢に戻るための時間であり，この期間で板を離す。この間の 10 秒間が物体を水平に保つ動作を行う 実際の稼働時間とし，図 9 はその間の実験結果を示している.

図 9(a) から，物体の傾きは最大でも約 $0.04 \mathrm{rad}\left(=2.29^{\circ}\right)$ に収まり，物体が常にほぼ水平に保たれていること が分かる. 図 9(b) からこの間にも物体は上下に激しく動いており, ロボットハンドがリアルタイムで物体の傾き をなくすよう正しく動作していることを表している.

図 10 に本実験の様子（約 0.83 秒毎の連続写真）を示す. 実験結果の動画は著者らのホームページから見ること ができる (石川渡辺研究室, 2015). この結果からも物体がほぼ水平に保たれていることが分かり, コップの位置も 


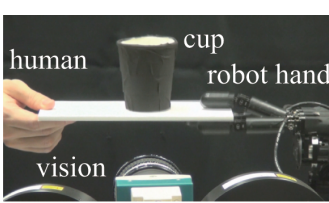

(a)

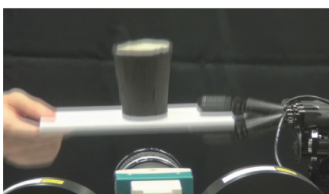

(e)

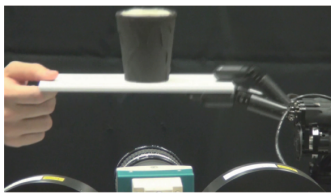

(i)

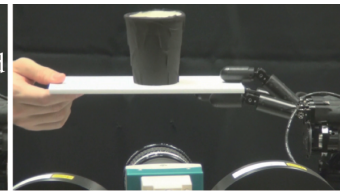

(b)

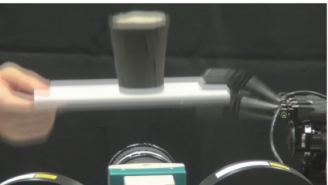

(f)

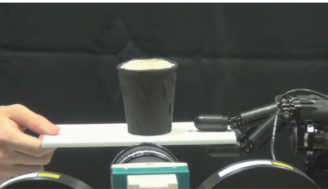

(j)

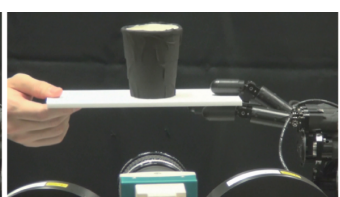

(c)

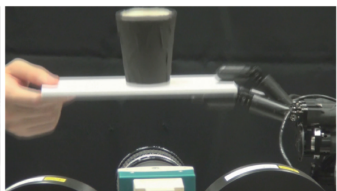

(g)

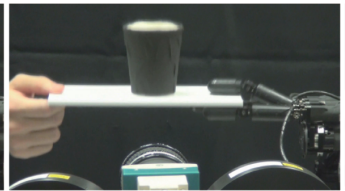

(k)

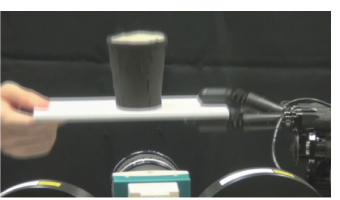

(d)

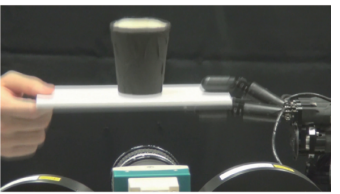

(h)

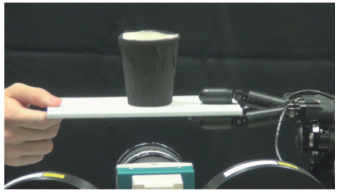

(1)

Fig. 10 Continuous photographs of experimental result

Table 3 Board angle in experimental result (frame rate: $640 \mathrm{fps}$ )

\begin{tabular}{|c|c|}
\hline & $\begin{array}{c}\text { Mean values of absolute value about } \\
\text { board angle during experiment [rad] }\end{array}$ \\
\hline \hline $\begin{array}{c}\text { Subject A } \\
\text { (man in his thirties) }\end{array}$ & 0.0144 \\
\cline { 2 - 2 } Subject B & 0.0131 \\
\cline { 2 - 2 } (man in his twenties) & 0.0126 \\
\hline
\end{tabular}

Table 4 Number in excess of 0.04 rad about board angle in experimental result (frame rate: $640 \mathrm{fps}$ )

\begin{tabular}{|c|c|}
\hline & Number \\
\hline \hline Subject A & 6 \\
\cline { 2 - 2 } (man in his thirties) & 2 \\
\hline Subject B & 2 \\
\cline { 2 - 2 } (man in his twenties) & 0 \\
\hline
\end{tabular}

ほぼ変化していない。また，PD 制御を行っているため関節の実際の角度と目標の角度には誤差が生じるが，大き な影響は無いことが確認できる。

表 3 と表 4 に各実験における物体の傾きの絶対值の平均值と物体の傾きが $0.04 \mathrm{rad}$ を超えた回数を示す．表 3 か ら物体の傾きの平均值は極めて小さく，実験結果全体の平均值も約 $0.0122 \mathrm{rad}\left(=0.7^{\circ}\right)$ であるため，物体はほぼ 水平に保持されていることが分かる. 加えて, 表 4 から物体の傾きが $0.04 \mathrm{rad}$ を超える回数も少ないことから, 提 案手法の有効性が定量的にも確認できる．被験者によって若干の差異は生じているが，この差異は無視できる範 囲と考えている.なお，図 9 は 20 代男性の 1 回目の実験結果の時系列データを示している.

\section{$4 \cdot 2$ フレームレート低下による挙動の変化}

前節の実験ではフレームレートを $640 \mathrm{fps}$ に設定し，物体を常にほぼ水平に保つことができた。しかし，仮にフ レームレートが低下した場合，システムの高速性が維持されず，提案する幾何学的な計算のみでロボットハンドの 制御を行うことにより物体を水平に保持することが困難になると考えられる.またその際，人間の手の運動に対す るロボットハンドの動作の遅れや，物体が大きく傾いたりと，人間が物体を動かす際に違和感を感じる可能性があ る。そこで, フレームレートを変化させながら, 前節と同様の実験を行い, 最低限どの程度のフレームレートが必 要かを検証する実験を行った。なお，フレームレート以外の実験条件は前節の実験条件と同様である. 被験者は 


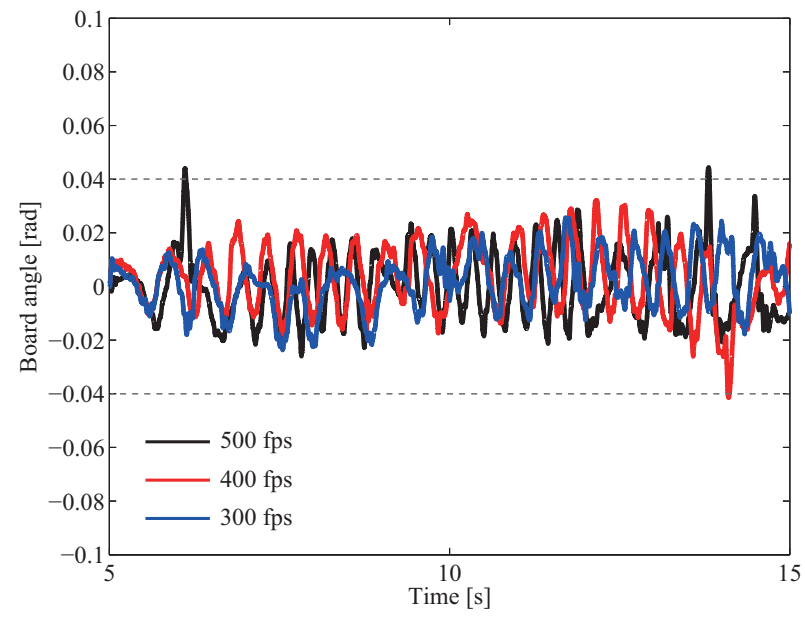

(a) Angle of object $\left(\theta_{m}\right)$

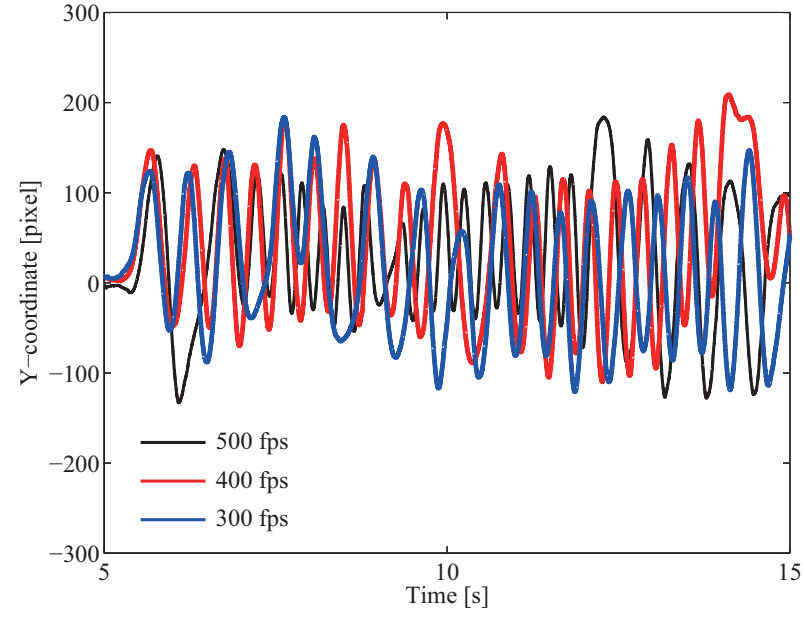

(b) $y$-coodinate of object $\left(g_{y}\right)$

Fig. 11 Experimental results (frame rate: 500 fps, $400 \mathrm{fps}, 300 \mathrm{fps}$ )

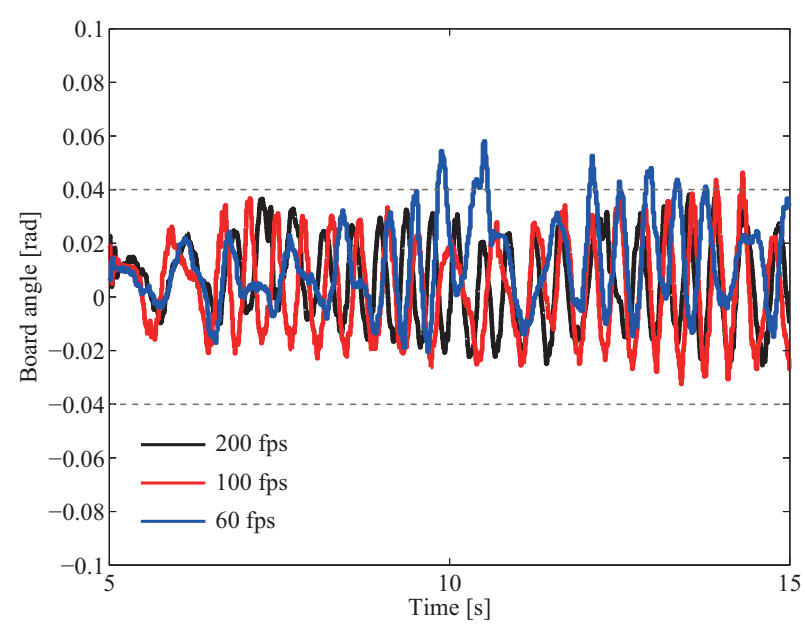

(a) Angle of object $\left(\theta_{m}\right)$

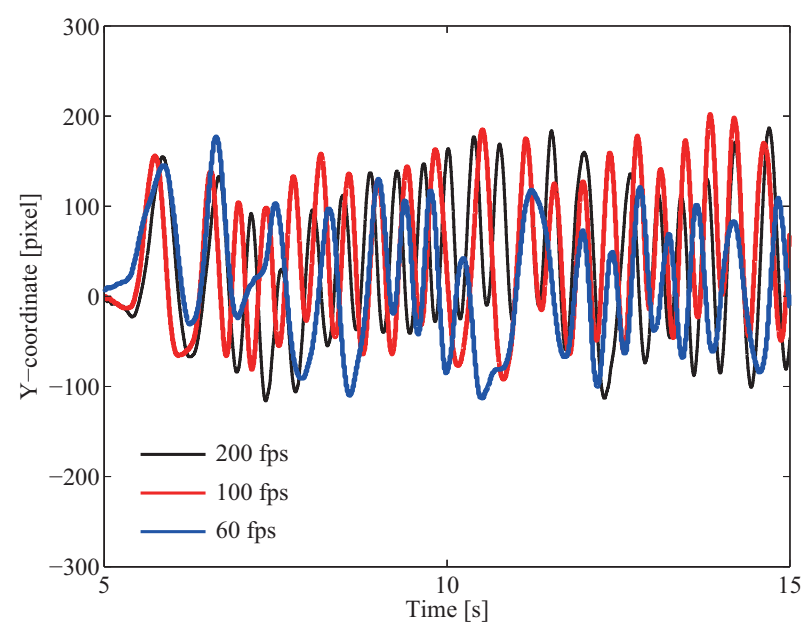

(b) $y$-coodinate of object $\left(g_{y}\right)$

Fig. 12 Experimental results (frame rate: $200 \mathrm{fps}, 100 \mathrm{fps}, 60 \mathrm{fps}$ )

30 代男性 1 名で, 各フレームレートに対して各 2 回実験を行った。前節の実験同様，被験者はシステムの動作を 理解した上で，物体をランダムに操作した。本来，被験者にフレームレートを事前に知らせずに実験を行うこと が望ましいと考えられるが, 被験者の安全性を確保するため, フレームレートを事前に知らせて本実験を行った. ただし，高フレームレートの場合とできる限り同じような速さで動きをするように指示した上で実験を行った。

フレームレートは, $500 \mathrm{fps}, 400 \mathrm{fps}, 300 \mathrm{fps}, 200 \mathrm{fps}, 100 \mathrm{fps}, 60 \mathrm{fps}$ の 6 パターンの場合について検討した. ロボットハンドの制御レートは $1 \mathrm{kHz}$ のままで, ロボットハンドの目標関節角度の更新レートが変化する. 図 11 $(500,400,300 \mathrm{fps})$, 図 $12(200,100,60 \mathrm{fps})$ に各フレームレートに対する実験結果（1 例）の物体の傾き（ $\left.\theta_{m}\right)$ と重心の $y$ 座標 $\left(g_{y}\right)$ を示す. さらに, 表 5 に各フレームレートへの各試行における物体の傾きの絶対值の平均值 を示す.

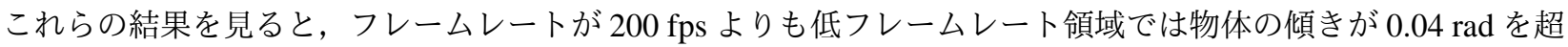
えるなど大きくなる傾向にあり，ロボットハンドによる人間の手の運動への追従が鈍くなっていることが分かる. 実際に, これらのフレームレートの下ではロボットハンドの動きは滑らかでなく, 動作するたびに振動が発生し た。このことから, 提案手法による幾何学的な計算のみでのロボットハンドの制御や人間が違和感を感じずに物 体を操作するためには，200 fps 程度以上のフレームレートが必要と考えられる. $60 \mathrm{fps}$ の物体の傾きが比較的小 さいのは, 被験者がシステムの動作遅延を認知し違和感を感じ, 物体への動作を制限したためと考えられる. 
Table 5 Board angle of experimental result in each frame rate

\begin{tabular}{|c|c|}
\hline Frame rate & $\begin{array}{c}\text { Mean values of absolute value about } \\
\text { board angle during experiment [rad] }\end{array}$ \\
\hline \hline \multirow{2}{*}{$60 \mathrm{fps}$} & 0.0162 \\
\cline { 2 - 3 } & 0.0148 \\
\hline \multirow{2}{*}{$100 \mathrm{fps}$} & 0.0186 \\
\cline { 2 - 3 } & 0.0154 \\
\hline \multirow{2}{*}{$200 \mathrm{fps}$} & 0.0182 \\
\cline { 2 - 3 } $300 \mathrm{fps}$ & 0.0143 \\
\cline { 2 - 3 } & 0.0158 \\
\hline \multirow{2}{*}{$400 \mathrm{fps}$} & 0.0082 \\
\cline { 2 - 3 } & 0.0136 \\
\hline \multirow{2}{*}{$500 \mathrm{fps}$} & 0.0109 \\
\cline { 2 - 3 } & 0.0124 \\
\hline
\end{tabular}

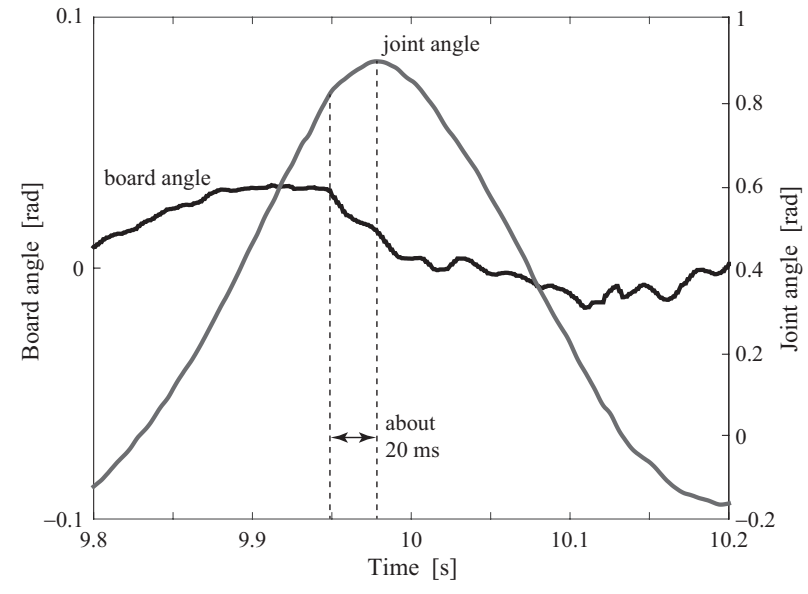

(a) $640 \mathrm{fps}$

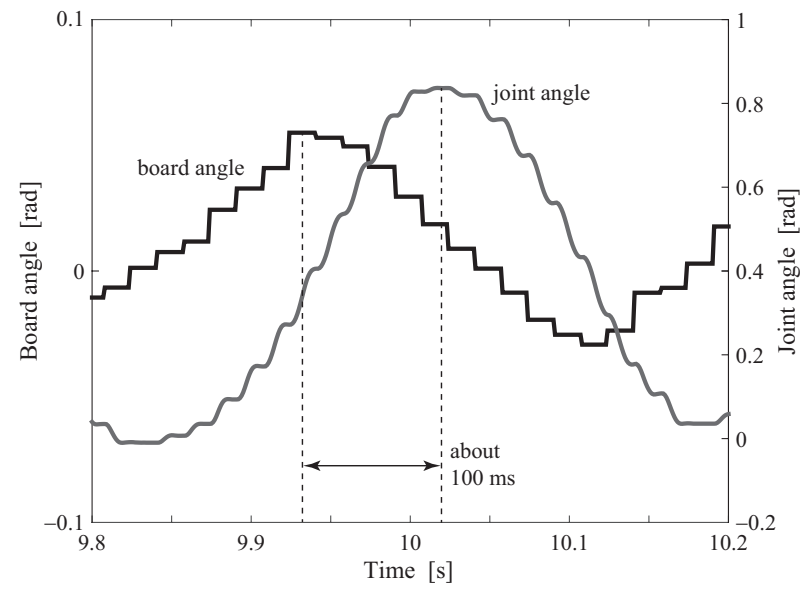

(b) $60 \mathrm{fps}$

Fig. 13 Experimental results (enlarged) (frame rate: $640 \mathrm{fps}$ and $60 \mathrm{fps}$ )

フレームレートを低下させることは制御レートを低下させることと等価であり，結果として制御システムの帯 域幅を狭くしている。これにより，傾きが大きくなったり，ロボットハンドの振動が起きたと考えられる. 本論文 ではフレームレートの低下について考察したが, 図 8 のブロック線図から分かるように, ロボットハンドの性能 （運動性能，制御性能）についても同様のことが言える.そのため，人間機械協調システムにおける提案手法にお いて，計測と制御の両面において高速性が重要であることがわかる.

なお， $500 \mathrm{fps} や 400 \mathrm{fps}$ において，物体の傾きが $0.04 \mathrm{rad}$ を超えるのは，物体の重心位置が上下に移動しすぎた ためにロボットハンドの関節角度の制限に達したためであり，本質的な問題点ではない.

\section{$4 \cdot 3$ 高フレームレートと低フレームレートとの比較}

システムの応答性を比較するために，高フレームレート（640 fps）と低フレームレート（60 fps）における同実 験結果の拡大図を図 13 に示す。図中の黒線は物体の傾きを，灰色線は左右指の根元リンクの実際の関節角度を示 している.フレームレートが低速（図 13(b)）になったことにより，関節角度の制御レートがフレームレートとと もに低速になり, 関節角度の動きが滑らかではなくなる. 特に板の角度がピーク值から減少する際に, ロボットハ ンドが動作するまでの反応時間が遅くなっていることがわかる.

さらに，1 ミリ秒の応答性を有する高速触覚センサ (石川, 下条, 1982) を指先リンクに設置し，同実験中に中指 


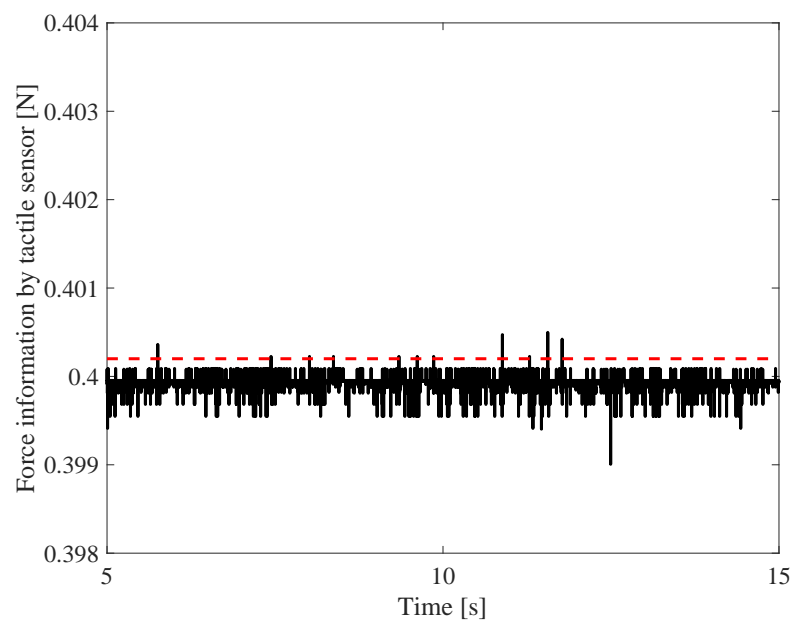

(a) $640 \mathrm{fps}$

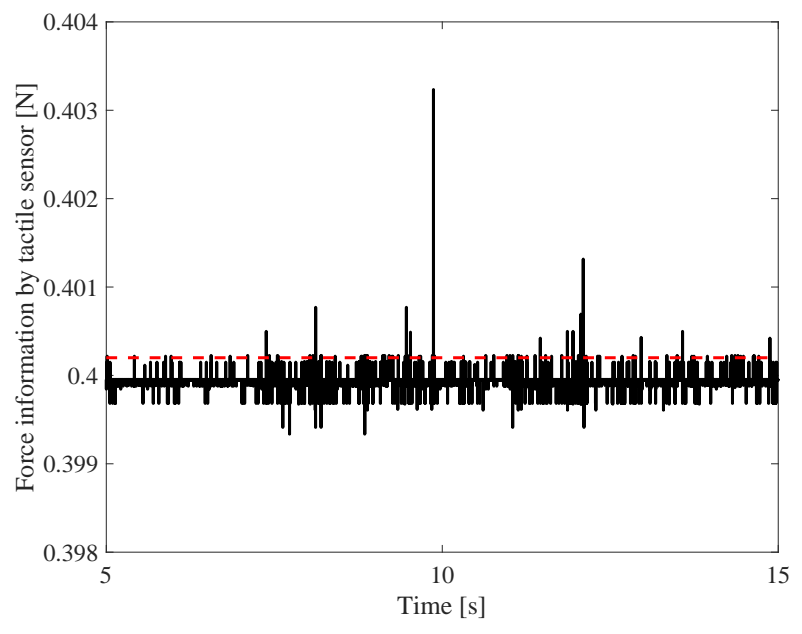

(b) $60 \mathrm{fps}$

Fig. 14 Experimental results of force data with high-speed tactile sensor (frame rate: $640 \mathrm{fps}$ and $60 \mathrm{fps}$ )

の指先リンクにかかる力を計測した．その結果を図 14 に示す. 図 14 から, 高速な応答性を有する場合（図 14(a), フレームレート：640fps）, 指先リンクに反力は加わらず，一定の小さな值を示している．一方，フレームレート を低速にした場合（図 14(b)，フレームレート：60 fps），瞬間的に反力が加わり大きな值を示し，ロボットハンド への負担が大きくなっていることがわかる，特に，物体の傾きが大きくなった際（図 12(a)）に大きな反力が加わ る傾向にあり, また平均的に反力が増加しており，ある值（0.4002 N (図 14 赤色破線)）以上になる頻度も高く なっていることが分かる。これは，フレームレートが低速になったことによりロボットシステムの反応が遅くな り，人間の動作に追従できず物体が水平状態から外れるため，物体からの力を受け易くなったと考えられる.

\section{5. 結言}

本論文では，高速ロボットシステムの人間機械協調系への応用を目指し，具体的なタスクとして一つの物体を 水平に支えるという動作を実現するための高速ロボットハンドシステム全体の提案を行った。特に，ロボットハ ンドによって物体を水平に保つための基本的な戦略を示し，画像処理及びロボット制御について具体的な方法を 提案した. 提案手法に基づいて, 実際にシステムを構築し, 物体を水平に保つタスクを実現した. 加えて, 高速 ビジョンのフレームレートを変化させ, タスク実現に要求される最低限のフレームレートについて検証を行った. 本研究によって得られた知見は以下の 3 点である.

1. 高速なビジョンとロボットハンドを用いることで，人間の高速かつランダムな動作に対して，一つの物体を 人間と協調して支えるという動作を実現した。

2. 人間機械協調において幾何学的な計算のみでロボットハンドが人間の手の動きに追従し, 人間が違和感を覚 えず物体を支えるための, 最低限必要とされるビジョンのフレームレートを明らかにした。これは制御レー トにも同様のことが言える.

3. 高速触覚センサを用いてロボットハンドへの反力を計測した結果, 高フレームレートでは大きな反力が加わ らずロボットへの負担が軽減されることが分かった。

特に，2.の知見はフレームレートに対して提案手法の適用可能範囲を示すとともに，過大なフレームレートを設 定する必要が無いことを示唆しており, その分画像処理時間を確保できるため, 複雑な画像処理認識を可能とし, より複雑なタスクにも応用可能であると考えられる.

今後の課題としては，本論文では物体の運動の自由度（物体の傾きと上下位置）を限定していたが，物体の様々 な位置・姿勢に対して物体が水平もしくは目標とする位置・姿勢に制御するためのシステムへと拡張する．さら に, 力の評価に使用した高速触覚センサ (石川, 下条, 1982) も用いて, 高速視触覚フィードバック系ヘとシステム を拡張するとともに力制御も導入し，高速かつロバストな人間機械協調動作の実現を目指す.

提案システムは高速性に特徵があるため, 将来的には人間がロボットの運動に注意することなく, 自由に協調動 
作を行うことができると考えられる．具体的な応用例としては，同一物体を把持した上での人間との物体搬送に 限らず，両手では困難なタスクに対する人間との協働作業や，ロボットハンドとは形を変えた高速なデバイスを用 いて，スキルアシストを目標とした人間の作業支援 (Bergström et al., 2016) や運動支援 (Tooyama et al., 2016) 等が 挙げられる. 加えて, システムが人間を先回りして支援すること等も応用例として考えられる.

\section{文献}

Al-jarrah, O. M. and Zheng, Y. F., Arm-manipulator coordination for load sharing using variable compliance control, Proceedings of the 1997 IEEE International Conference on Robotics and Automation (1997), pp.895-900.

Bergström, N., Huang, S., Yamakawa, Y., Senoo, T. and Ishikawa, M., Towards assistive human-robot micro manipulation, Proceedings of the 2016 IEEE-RAS International Conference on Humanoid Robots (2016), pp.1188-1195.

Hayashibara, Y., Sonoda, Y., Takubo, T., Arai, H. and Tanie, K., Assist system for carrying a long object with a human -analysis of a human cooperative behavior in the vertical direction-, Proceedings of the 1999 IEEE/RSJ International Conference on Intelligent Robots and Systems (1999), pp.695-700.

池浦良淳, ロボットー人間協調システムのモデリング, 日本ロボット学会誌, Vol.18, No.3 (2000a), pp.331-336.

池浦良淳, 人間とロボットによる協調作業, システム/制御/情報, Vol.44, No.12 (2000b), pp.682-687.

石川正俊, 下条誠, 感圧導電性ゴムを用いた 2 次元分布荷重の中心の位置の測定方法, 計測自動制御学会論文集, Vol.18, No.7 (1982), pp.730-735.

石川渡辺研究室, 高速ビジョンとロボットハンドを用いた人間協調システム, available from $<$ http://www.k2.t.utokyo.ac.jp/fusion/Cooperation/index-e.html> (参照日 2015 年 11 月 30 日)

Kazerooni, H., A controller design framework for telerobotic systems, IEEE Transactions on Control Systems Technology, Vol.1, No.1 (1993), pp.50-62.

Kazerooni, H., The human power amplifier technology at the University of California, Berkeley, Journal of the Society of Instrument and Control Engineers, Vol.34, No.4 (1995), pp.291-298.

小菅一弘, 風村典秀, 佐藤学, 荒尾真樹, 恵木守, 河野淳一, 島村純児, 人間協調型ロボットを用いた物体の協調持ち上 げ動作, 日本機械学会ロボティクス・メカトロニクス講演会 (1999), 1P2-75-105.

Nakai, K., Kosuge, K. and Hirata, Y., Control of robot in singular configurations for human-robot coordination, Proceedings of the 2002 IEEE International Workshop on Robot and Human Interactive Communication (2002), pp.356-361.

中内靖, 安西祐一郎, ヒューマン・群知能ロボット・インタフェースシステムー人間とロボットの協調について-, 計 測と制御, Vol.31, No.11 (1992), pp.1167-1172.

並木明夫, 石井抱, 石川正俊, 高速センサフィードバックに基づく把握行動, 日本ロボット学会誌, Vol.20, No.7 (2002), pp.47-56.

Namiki, A., Imai, Y., Ishikawa, M. and Kaneko, M., Development of a high-speed multifingered hand system and its application to catching, Proceedings of the 2003 IEEE/RSJ International Conference on Intelligent Robots and Systems (2003), pp.2666-2671.

佐藤知正, 人間機械協調システム, 計測と制御, Vol.35, No.4 (1996), pp.262-267.

佐藤知正, 森武俊, 人と機械の知的協調システム-行動蓄積機能に基づいた人間行動適合型機械システム-, 計測と制 御, Vol.38, No.6 (1999), pp.357-362.

妹尾拓, 並木明夫, 石川正俊, 高速打撃動作における多関節マニピュレータのハイブリッド軌道生成, 日本ロボット 学会誌, Vol.24, No.4 (2006), pp.515-522.

玉田智樹, 五十嵐渉, 米山大揮, 田中和仁, 山川雄司, 妹尾拓, 石川正俊, 高速 2 足走行システム ACHIRES の開発, 日 本ロボット学会誌, Vol.33, No.7 (2015), pp.482-489.

Tooyama, W., Huang, S., Murakami, K., Yamakawa, Y. and Ishikawa, M., Development of an assistive system for position control of a human hand with high speed and high accuracy, Proceedings of the 2016 IEEE-RAS International Conference on Humanoid Robots (2016), pp.230-235.

Yamakawa, Y., Kuno, K. and Ishikawa, M., Human-robot cooperative task realization using high-speed robot hand system, Proceedings of the 2015 IEEE International Conference on Advanced Intelligent Mechatronics (2015), 
pp.281-286.

Yokoyama, K., Handa, H., Isozumi, T., Fukase Y., Kaneko, K., Kanehiro, F., Kawai, Y., Tomita, F. and Hirukawa, H., Cooperative works by a human and a humanoid robot, Proceedings of the 2003 IEEE International Conference on Robotics and Automation (2003), pp.2985-2991.

\section{References}

Al-jarrah, O. M. and Zheng, Y. F., Arm-manipulator coordination for load sharing using variable compliance control, Proceedings of the 1997 IEEE International Conference on Robotics and Automation (1997), pp.895-900.

Bergström, N., Huang, S., Yamakawa, Y., Senoo, T. and Ishikawa, M., Towards assistive human-robot micro manipulation, Proceedings of the 2016 IEEE-RAS International Conference on Humanoid Robots (2016), pp.1188-1195.

Hayashibara, Y., Sonoda, Y., Takubo, T., Arai, H. and Tanie, K., Assist system for carrying a long object with a human -analysis of a human cooperative behavior in the vertical direction-, Proceedings of the 1999 IEEE/RSJ International Conference on Intelligent Robots and Systems (1999), pp.695-700.

Ikeura, R., Modeling for cooperative systems of human and robot, Journal of Robotics Society Japan, Vol.18, No.3 (2000a), pp.331-336 (in Japanese).

Ikeura, R., Cooperative task by human and robot, Institute of Systems, Control and Information Engineers, Vol.44, No.12 (2000b), pp.682-687 (in Japanese).

Ishikawa, M. and Shimojo, M., A method for measuring the center position of a two dimensional distributed load using pressure-conductive rubber, Transactions of the Society of Instrument and Control Engineers, Vol.18, No.7 (1982), pp.730-735 (in Japanese).

Ishikawa Watanabe Laboratory, Human-robot cooperative system using a high-speed vision system and a robot hand, available from < http://www.k2.t.u-tokyo.ac.jp/fusion/Cooperation/index-e.html > (accessed on 30 November, 2015)

Kazerooni, H., A controller design framework for telerobotic systems, IEEE Transactions on Control Systems Technology, Vol.1, No.1 (1993), pp.50-62.

Kazerooni, H., The human power amplifier technology at the University of California, Berkeley, Journal of the Society of Instrument and Control Engineers, Vol.34, No.4 (1995), pp.291-298.

Kosuge, K., Kazamura, N., Sato, M., Arao, M., Egi, M., Kawano, J. and Shimamura, J., Cooperative lifting-up of object by robot and human, Proceedings of The Robotics and Mechatronics Conference 1999 (1999), 1P2-75-105 (in Japanese).

Nakai, K., Kosuge, K. and Hirata, Y., Control of robot in singular configurations for human-robot coordination, Proceedings of the 2002 IEEE International Workshop on Robot and Human Interactive Communication (2002), pp.356-361.

Nakauchi, Y. and Anzai, Y., Human and intelligent multi-robot interface system -towards cooperation of humans and robots-, Journal of the Society of Instrument and Control Engineers, Vol.31, No.11 (1992), pp.1167-1172 (in Japanese).

Namiki, A., Ishii, I. and Ishikawa, M., Grasping using high-speed sensory feedback, Journal of Robotics Society Japan, Vol.20, No.7 (2002), pp.47-56 (in Japanese).

Namiki, A., Imai, Y., Ishikawa, M. and Kaneko, M., Development of a high-speed multifingered hand system and its application to catching, Proceedings of the 2003 IEEE/RSJ Int. Conf. on Intelligent Robots and Systems (2003), pp.2666-2671.

Sato, T., Human machine cooperative system, Journal of the Society of Instrument and Control Engineers, Vol.35, No.4 (1996), pp.262-267 (in Japanese).

Sato, T. and Mori, T., Intelligent human-robot cooperative system -human behavior custumizing system based on behavior accumulation-, Journal of the Society of Instrument and Control Engineers, Vol.38, No.6 (1999), pp.357-362 (in Japanese).

Senoo, T., Namiki, A. and Ishikawa, M., Hybrid trajectory generation of an articulated manipulator for high-speed batting, Journal of Robotics Society Japan, Vol.24, No.4 (2006), pp.515-522 (in Japanese). 
Tamada, T., Ikarashi, W., Yoneyama, D., Tanaka, K., Yamakawa, Y., Senoo, T. and Ishikawa, M., Development of highspeed bipedal running robot system (ACHIRES), Journal of Robotics Society Japan, Vol.33, No.7 (2015), pp.482-489 (in Japanese).

Tooyama, W., Huang, S., Murakami, K., Yamakawa, Y. and Ishikawa, M., Development of an assistive system for position control of a human hand with high speed and high accuracy, Proceedings of the 2016 IEEE-RAS International Conference on Humanoid Robots (2016), pp.230-235.

Yamakawa, Y., Kuno, K. and Ishikawa, M., Human-robot cooperative task realization using high-speed robot hand system, Proceedins of the 2015 IEEE International Conference on Advanced Intelligent Mechatronics (2015), pp.281-286.

Yokoyama, K., Handa, H., Isozumi, T., Fukase Y., Kaneko, K., Kanehiro, F., Kawai, Y., Tomita, F. and Hirukawa, H., Cooperative works by a human and a humanoid robot, Proceedings of the 2003 IEEE International Conference on Robotics and Automation (2003), pp.2985-2991. 